\title{
A new Rhodococcus aetherivorans strain isolated from lubricant-contaminated soil as a prospective phenol-biodegrading agent
}

\author{
Taisiya Nogina ${ }^{1}$ - Marina Fomina ${ }^{1} \cdot$ Tatiana Dumanskaya $^{1}$ - Liubov Zelena ${ }^{1} \cdot$ Lyudmila Khomenko $^{1}$. \\ Sergey Mikhalovsky ${ }^{2,3} \cdot$ Valentin Podgorskyi $^{1} \cdot$ Geoffrey Michael Gadd ${ }^{4,5}$ (I)
}

Received: 30 August 2019 / Revised: 3 January 2020 / Accepted: 16 January 2020 / Published online: 11 February 2020

(C) The Author(s) 2020, corrected publication 2020

\begin{abstract}
Microbe-based decontamination of phenol-polluted environments has significant advantages over physical and chemical approaches by being relatively cheaper and ensuring complete phenol degradation. There is a need to search for commercially prospective bacterial strains that are resistant to phenol and other co-pollutants, e.g. oil hydrocarbons, in contaminated environments, and able to carry out efficient phenol biodegradation at a variable range of concentrations. This research characterizes the phenol-biodegrading ability of a new actinobacteria strain isolated from a lubricant-contaminated soil environment. Phenotypic and phylogenetic analyses showed that the novel strain UCM Ac-603 belonged to the species Rhodococcus aetherivorans, and phenol degrading ability was quantitatively characterized for the first time. R. aetherivorans UCM Ac-603 tolerated and assimilated phenol (100\% of supplied concentration) and various hydrocarbons (56.2-94.4\%) as sole carbon sources. Additional nutrient supplementation was not required for degradation and this organism could grow at a phenol concentration of $500 \mathrm{mg} \mathrm{L}^{-1}$ without inhibition. Complete phenol assimilation occurred after 4 days at an initial concentration of $1750 \mathrm{mg} \mathrm{L}^{-1}$ for freely-suspended cells and at $2000 \mathrm{mg} \mathrm{L}^{-1}$ for vermiculite-immobilized cells: $99.9 \%$ assimilation of phenol was possible from a total concentration of $3000 \mathrm{~m} \mathrm{~L}^{-1}$ supplied at daily fractional phenol additions of $750 \mathrm{mg} \mathrm{L}^{-1}$ over 4 days. In terms of phenol degradation rates, $R$. aetherivorans UCM Ac-602 showed efficient phenol degradation over a wide range of initial concentrations with the rates (e.g. $35.7 \mathrm{mg} \mathrm{L}^{-1} \mathrm{~h}^{-1}$ at $500 \mathrm{mg} \mathrm{L}^{-1}$ phenol, and $18.2 \mathrm{mg} \mathrm{L}^{-1} \mathrm{~h}^{-1}$ at $1750 \mathrm{mg} \mathrm{L}^{-1}$ phenol) significantly exceeding (1.2-5 times) reported data for almost all other phenol-assimilating bacteria. Such efficient phenol degradation ability compared to currently known strains and other beneficial characteristics of $R$. aetherivorans UCM Ac-602 suggest it is a promising candidate for bioremediation of phenol-contaminated environments.
\end{abstract}

Keywords Phenol biodegradation - Actinobacteria $\cdot$ Rhodococcus aetherivorans $\cdot$ Cell immobilization - Xenobiotics . Bioremediation

Geoffrey Michael Gadd

g.m.gadd@dundee.ac.uk

Taisiya Nogina

tnogina@ukr.net

Marina Fomina

M.Fomina@ukr.net

Tatiana Dumanskaya

dumanska@imv.kiev.ua

Liubov Zelena

zelenalyubov@gmail.com

Lyudmila Khomenko

homenkolud@ukr.net

Sergey Mikhalovsky

sergeymikhalovsky@gmail.com
Valentin Podgorskyi

podgorsky@serv.imv.kiev.ua

1 Zabolotny Institute of Microbiology and Virology of National Academy of Sciences of Ukraine, Zabolotny str., 154, Kyiv 03143 , Ukraine

2 ANAMAD Ltd, Sussex Innovation Centre, Science Park Square, Falmer, Brighton BN1 9SB, UK

3 Chuiko Institute of Surface Chemistry, 17, General Naumov Street, Kyiv 03164, Ukraine

4 Geomicrobiology Group, School of Life Sciences, University of Dundee, Dundee, Scotland DD1 5EH, UK

5 State Key Laboratory of Heavy Oil Processing, Beijing Key Laboratory of Oil and Gas Pollution Control, College of Chemical Engineering and Environment, China University of Petroleum, Beijing 102249, China 


\section{Introduction}

Phenols are the main pollutants of effluents and wastes of petrochemical, wood-chemical, pharmaceutical and plastics industries. Due to their high toxicity, even at low concentrations, ubiquity and resistance to degradation, they are considered to be particularly hazardous environmental pollutants (Gami et al. 2014; Paisio et al. 2014). A phenol concentration of $1 \mathrm{mg} \mathrm{L}^{-1}$ can affect aquatic life and be harmful to human health. The World Health Organization established a maximum permitted concentration of $1 \mu \mathrm{g} \mathrm{L}^{-1}$ for phenolic compounds in drinking water (Paisio et al. 2014). However, the purification of phenol-containing industrial wastewaters and contaminated environments is currently an important problem (Michalowicz and Duda 2007; Gami et al. 2014; Paisio et al. 2014). Physico-chemical methods such as reverse osmosis, ozonation, electrolytic oxidation and photocatalysis can be effective for phenol degradation in industrial wastewater (Lin and Chuang 1994; Shaban et al. 2013) but they are complex, expensive and frequently produce other toxic end-products, e.g. the conversion of phenol to chlorophenol when using chlorination (Marrot et al. 2006). Biological methods of phenol decontamination based on the use of phenolbiodegrading microorganisms may have advantages over physical and chemical treatments as they require relatively small investment and low power consumption as well as being capable of complete phenol degradation to carbon dioxide and water (Gami et al. 2014; Paisio et al. 2014). One of the flaws of conventional physico-chemical methods is that they are not able to reduce the phenol concentration to environmentally safe values. For example, physico-chemical treatment of contaminated industrial sewage at petrochemical enterprises by adsorption, evaporation and extraction reduces the phenol content from 2000 to $6000 \mathrm{mg} \mathrm{L}{ }^{-1}$ to only $80-400 \mathrm{mg} \cdot \mathrm{L}^{-1}$ which still requires additional post-treatment using biochemical methods to reduce the phenol content to $2-5 \mathrm{mgL}^{-1}$ (Smirnova et al. 2017).

Phenol-utilizing microorganisms are capable of degrading phenol to non-toxic intermediates of the tricarboxylic acid (Krebs) cycle through ortho- or meta-cleavage pathways (Park et al. 2009; Paisio et al. 2014; Kim and Gadd 2019). To improve the efficacy of phenol degradation by microorganisms, many strategies have been proposed including an increase in size of the bacterial inoculum, co-metabolism by introduction of an additional conventional substrate (e.g. glucose or yeast extract), the use of bacterial consortia and immobilized cells as well as sequential fractional additions of substrate (Shumkova et al. 2009; Soudi and Kolahchi. 2011; Paisio et al. 2014; AlDefiery and Gopal 2015). Bacterial species of the Acinetobacter, Arthrobacter, Bacillus, Pseudomonas and Rhodococcus genera are often identified as capable of phenol biodegradation (Paisio et al. 2014). However, only a few of them are able to metabolize the high phenol concentrations that can be found in anthropogenic wastes. According to several authors, one of the most promising groups of microorganisms suitable for bioremediation of phenol-polluted environments are actinobacteria of the genus Rhodococcus (Shumkova et al. 2009; Solyanikova et al. 2010; Suhaila et al. 2010, 2013; Soudi and Kolahchi 2011; Mishra and Lal 2014; AlDefiery and Gopal 2015; Moghadam et al. 2016). The ubiquity of Rhodococcus spp. in nature, their broad catabolic versatility and physiological and ecological adaptability to extreme environmental conditions make them suitable candidates for biodegradation of persistent xenobiotics and bioremediation (Martínková et al. 2009; Kuyukina and Ivshina 2010; Solyanikova et al. 2010; Solyanikova and Golovleva 2015).

The majority of phenol-utilizing microorganisms are reported to grow at a maximum concentration of $600 \mathrm{mg} \mathrm{L}^{-1}$ (Paisio et al. 2014; Smirnova et al. 2017). Concentration values for phenol in anthropogenic sources show a wide range: phenol concentrations from petroleum refinery effluents vary between 50 and $2000 \mathrm{mg} \mathrm{L}^{-1}$, from distillation units and olive mill wastewater between 1200 and $4300 \mathrm{mg} \mathrm{L}^{-1}$ and from highly concentrated wastewater from coke-chemical and petrochemical enterprises between 5000 and $10,000 \mathrm{mg} \mathrm{L}^{-1}$ (Paisio et al. 2014; Smirnova et al. 2017). Phenol-containing wastewaters and contaminated soils are also usually accompanied by other industrial pollutants including oil hydrocarbons. Considering that the efficiency of microbial phenol degradation is strain specific, it follows that there is a need to search for new strains resistant to highly polluted environments and which are able to efficiently perform phenol biodegradation while withstanding variability in concentration and the presence of oil hydrocarbon co-contaminants. The aim of this work was therefore to study the phenolbiodegrading ability of an actinobacteria strain newly isolated from lubricant-contaminated soil.

\section{Materials and methods}

\section{Chemicals}

All chemicals used in this study were of analytical grade (Merck, Kenilworth, NJ, USA). Phenol was of chromatography grade (purity $99.5 \%$, Merck). Commercial diesel fuel 'Euro 5' was obtained from PJSC Ukrtatnafta (Kremenchug, Poltava region, Ukraine), transformer oil 'NITRO 11 GX' from Nynas Naphthenics (Stockholm, Sweden) and expanded vermiculite (fraction size $4 \mathrm{~mm}$ ) from the Ukrainian Vermiculite Group LLC (Vasil'kov, Kiev region, Ukraine). The chemical composition of vermiculite (\%, expressed as oxides) was $\mathrm{SiO}_{2}$ (33-36); $\mathrm{Fe}_{2} \mathrm{O}_{3}(5-17) ; \mathrm{FeO}(0.2-0.27)$; $\mathrm{Al}_{2} \mathrm{O}_{3}$ (6-18); $\mathrm{MgO}$ (14-25); $\mathrm{CaO}$ (1.2-2); $\mathrm{K}_{2} \mathrm{O}$ (3-5); $\mathrm{Mn}$ (0.05-0.07); $\mathrm{Na}_{2} \mathrm{O}(0.5) ; \mathrm{TiO}_{2}(0.4-0.47) ; \mathrm{pH}\left(\mathrm{H}_{2} \mathrm{O}\right) 6.8-7.0$ (http://uvg.org.ua/eng/descriptions/). 


\section{Microorganisms}

The bacterial strain was isolated from lubricantcontaminated soil at the locomotive depot of Odessa railway station (Odessa, Ukraine). A pure culture was obtained by the serial dilution $\left(10^{-1}\right)$ method followed by the spread plate technique using agar medium 53 (Corynebacterium agar) containing $\left(\mathrm{L}^{-1}\right.$ distilled water): $10.0 \mathrm{~g}$ casein peptone, tryptic digest, $5.0 \mathrm{~g}$ yeast extract, $5.0 \mathrm{~g}$ glucose, $5.0 \mathrm{~g} \mathrm{NaCl}, 15 \mathrm{~g}$ agar (DSMZ medium 53, www.dsmz.de). In addition, $200 \mathrm{mg} \mathrm{L}^{-1}$ phenol was added to the medium. The plates were incubated at $28{ }^{\circ} \mathrm{C}$ for 5 days. Morphologically different colonies were transferred onto agar medium 53 slants and the growth cycle of pure cultures examined using light microscopy after 16, 18, 24, 48 and $72 \mathrm{~h}$ of growth. The strain, UCM Ac-602, that showed a rod-coccus growth cycle was used for further studies. This strain was stored on agar medium 53 containing $200 \mathrm{mg} \mathrm{L}^{-1}$ phenol at $5{ }^{\circ} \mathrm{C}$ in the Ukrainian Collection of Microorganisms (UCM) of the Zabolotny Institute of Microbiology and Virology, National Academy of Sciences of Ukraine, Kyiv, Ukraine. Type strains of Rhodococcus rhodochrous UCM Ac-744 (= DSMZ 43241) and Rhodococcus ruber UCM Ac-745 (= DSMZ 43338) were obtained from the UCM to use as reference Rhodococcus species.

\section{Media and culture conditions}

For chemotaxonomic studies, the organism was grown for $48 \mathrm{~h}$ in $750 \mathrm{~mL}$ Erlenmeyer flasks containing $100 \mathrm{~mL}$ of liquid agar-free medium 53 on a rotary shaker $(220 \mathrm{rpm})$ at $28{ }^{\circ} \mathrm{C}$. The biomass was harvested by centrifugation for $15 \mathrm{~min}$ at $5000 \mathrm{rpm}$, washed twice in distilled water and freeze-dried. For phylogenetic analysis, the cells were grown on agar medium 53, washed in NaCl/EDTA buffer (0.1 M EDTA, 0.1 M $\mathrm{NaCl}, \mathrm{pH}$ 8.0) and stored until use at $-20^{\circ} \mathrm{C}$. Estimation of the degradation efficiency for oil hydrocarbons was performed using cells grown for $72 \mathrm{~h}$ in liquid mineral medium $\mathrm{N} 1$ containing ( $\mathrm{L}^{-1}$ distilled water): $3.0 \mathrm{~g} \mathrm{KNO}_{3}, 0.28 \mathrm{~g} \mathrm{KH}_{2} \mathrm{PO}_{4}$, $1.2 \mathrm{~g} \mathrm{Na}_{2} \mathrm{HPO}_{4} .12 \mathrm{H}_{2} \mathrm{O}, 2.0 \mathrm{~g} \mathrm{NaCI}, 0.2 \mathrm{~g} \mathrm{MgSO}_{4} .7 \mathrm{H}_{2} \mathrm{O}$, $17.9 \mathrm{mg} \mathrm{CaCl} 2 \cdot 6 \mathrm{H}_{2} \mathrm{O}, 19.9 \mathrm{mg} \mathrm{FeSO}_{4} .7 \mathrm{H}_{2} \mathrm{O}, 1.0$ g yeast extract, $\mathrm{pH}$ 6.8-7.0. Kerosene, n-hexadecane, diesel or transformer oil were added into the medium to $0.5 \%(v / v)$. A suspension of cells pre-grown on agar medium 53 for $48 \mathrm{~h}$ was used as an inoculum.

The experiments on growth and degradation of phenol by the bacterial strain were carried out in liquid mineral medium $\mathrm{N} 2$ containing ( $\mathrm{L}^{-1}$ distilled water): $0.75 \mathrm{~g} \mathrm{NH}_{4} \mathrm{NO}_{3}, 0.73 \mathrm{~g}$ $\mathrm{Na}_{2} \mathrm{HPO}_{4}, 0.35 \mathrm{~g} \mathrm{KH}_{2} \mathrm{PO}_{4}, 0.25 \mathrm{~g} \mathrm{NaHCO}_{3}, 0.1 \mathrm{~g}$ $\mathrm{MgSO}_{4} .7 \mathrm{H}_{2} \mathrm{O}, 0.002 \mathrm{~g} \mathrm{MnSO}_{4}, 0.02 \mathrm{~g} \mathrm{FeSO}_{4} .7 \mathrm{H}_{2} \mathrm{O} ; \mathrm{pH}$ 7.0-7.2 (Shumkova et al. 2009). Phenol was filter sterilized using $0.2 \mu \mathrm{m}$ regenerated cellulose membrane filters
(Sartorius Stedim, Goettingen, Germany) and added, from 200 to $2000 \mathrm{mg} \mathrm{L}^{-1}$, to the autoclaved medium after cooling to room temperature. Bacterial growth was measured by optical density at $540 \mathrm{~nm}\left(\mathrm{OD}_{540}\right)$ using a photocolorimeter KFK2MP (Zagorsk Optical and Mechanical Plant, Zagorsk, Russia). Phenol degradation by freely-suspended bacterial cells at initial substrate concentrations of 200, 300, 500 and $750 \mathrm{mg} \mathrm{L}^{-1}$ was studied by growing bacteria for $24 \mathrm{~h}$. Samples were taken at regular intervals $(2 \mathrm{~h})$ and analysed for growth and phenol degradation. At the initial phenol concentrations of 1000 and $1500 \mathrm{mg} \mathrm{L}^{-1}$, the strain was cultivated for $72 \mathrm{~h}$ : at an initial phenol concentration of 1750 $2000 \mathrm{mg} \mathrm{L}^{-1}$, it was grown for $144 \mathrm{~h}$. Samples were taken every $8 \mathrm{~h}$ at phenol concentrations of 1000 and $1500 \mathrm{mg} \mathrm{L}^{-1}$ and every $24 \mathrm{~h}$ at concentrations of 1750 and $2000 \mathrm{mg} \mathrm{L}^{-1}$. Investigation of phenol degradation by immobilized cells was carried out in flasks containing $100 \mathrm{~mL}$ medium, $2.5 \mathrm{~g}$ vermiculite with immobilized cells and $2000 \mathrm{mg} \mathrm{L}^{-1}$ phenol. To test the ability of vermiculite to sorb phenol, an abiotic control without microorganisms in a medium with $2000 \mathrm{mg} \mathrm{L}^{-1}$ phenol and $2.5 \mathrm{~g}$ vermiculite was used. Culture conditions in this experiment were the same as for freely-suspended bacterial cells at $2000 \mathrm{mg} \mathrm{L}^{-1}$ phenol. In all experiments, a 48-h inoculum was used of bacteria grown on phenol-containing medium N2 with fractional phenol addition: initial cultivation was at a phenol concentration of $500 \mathrm{mg} \mathrm{L}^{-1}$ for $24 \mathrm{~h}$ which was then followed by the next phenol $\left(500 \mathrm{mg} \mathrm{L}^{-1}\right)$ addition and continued cultivation for $24 \mathrm{~h}$. For determination of freelysuspended bacterial cell viability at an initial phenol concentration of $2000 \mathrm{mg} \mathrm{L}^{-1}$, samples were serially diluted and plated on agar medium 53. To study the effect of fractional phenol addition on degradation, an initial phenol concentration of $750 \mathrm{mg} \mathrm{L}^{-1}$ was used for $96 \mathrm{~h}$ in medium N2 with subsequent phenol additions to the culture every $24 \mathrm{~h}$.

\section{Phenotypic properties}

Cell morphology was examined using a Carl Zeiss Primo Star light microscope (Zeiss, Jena, Germany). Gram staining, motility, oxidase and catalase activity, gelatin and casein hydrolysis and nitrate reduction were tested using standard procedures (Smibert and Krieg 1994). For detection of the aromatic ring cleavage mechanism, the strain was grown for $24 \mathrm{~h}$ on medium N2 at an initial phenol concentration of $500 \mathrm{mg} \mathrm{L}^{-1}$. Cells were harvested from a $30 \mathrm{~mL}$ broth culture by centrifugation $\left(5000 \mathrm{rpm}, 15 \mathrm{~min}, 4{ }^{\circ} \mathrm{C}\right)$. The presence of the $\beta$ ketoadipate pathway (indicating ortho-cleavage) was suggested qualitatively by the Rothera reaction according to the method of Ottow and Zolg (1974). Other physiological and biochemical properties were determined as described by Goodfellow et al. (1990). Established methods were also used for detection of isomers of 2,6-diaminopimelic acid, analysis of whole-cell sugars (Staneck and Roberts 1974) and mycolic 
acids (Minnikin et al. 1980) using type strains of $R$. rhodochrous UCM Ac-744 and R. ruber UCM Ac-745 as controls. Fatty acid methyl esters in whole cells were prepared by cell hydrolysis in a $5 \%$ solution of acetyl chloride in methanol for $4 \mathrm{~h}$ at $100{ }^{\circ} \mathrm{C}$ followed by extraction with ether:hexane (1:1). Identification of methyl esters was performed using a gas chromatography-mass spectrometry system (Agilent 6800N/5973inert, Agilent Technologies, Santa Clara, CA, USA) and identified based on their retention time by comparison with standards. Fatty acid content was determined using Agilent Chem Station software and was expressed as a percentage (\%) of total peak area.

\section{Phylogenetic analysis}

Bacterial DNA was isolated from a 24-h culture using the DNA isolation kit 'DNA-sorb B' (AmpliSens, Moscow, Russia) according to the manufacturer's instructions. 16S rRNA gene amplification was performed with primers $27 \mathrm{f}$ and 1492r as described by Lane (1991). PCR-product sequencing was carried out using ABI 310 (Applied Biosystems) with the 'BigDye Terminator v3.1 Cycle Sequencing Kit' (ThermoFisher Scientific, Waltham, MA, USA) and the $1492 \mathrm{r}$ primer. The resulted nucleotide fragment of the 16S rRNA gene sequence was compared with homologous sequences available in the GenBank database using the NCBI Blast program (http://www.ncbi.nlm.nih.gov/blast). Phylogenetic analysis was carried out using MEGA5 program (Tamura et al. 2011), a dendrogram was constructed with the neighbour-joining method and Kimura's twoparameter model (Kimura 1980; Saitou and Nei 1987). Then, 1000-replica bootstrap was used for providing tree topology confidence. The 16S rRNA gene sequences of Rhodococcus species were obtained from the GenBank database and the web-resource www.straininfo.net.

\section{Determination of hydrocarbon and phenol degradation efficiency}

The total amount of petroleum hydrocarbons was determined by IR spectrometry using a laboratory analyser of petroleum products in water AN-1 (Neftehimavtomatika$\mathrm{SPb}$, St Petersburg, Russia) according to the manufacturer's instructions. The phenol concentration was determined by a direct photometric method using 4aminoantipyrine according to the American Public Health Association (APHA) (2005). The hydrocarbon (h) or phenol $(\mathrm{p})$ degradation efficiency $\left(\mathrm{DE}_{\mathrm{h}}\right.$ or $\left.\mathrm{DE}_{\mathrm{p}}\right)$ was evaluated as a percentage (\%) and calculated according to the formula: $\mathrm{DE}_{\mathrm{h}}$ or $\mathrm{DE}_{\mathrm{p}}(\%)=100 \%-\left[C_{2} \times 100 \% /\right.$ $C_{1}$ ], where $C_{1}$ is the primary hydrocarbon or phenol substrate concentration in a sample, $\mathrm{mg} \mathrm{L}^{-1} ; C_{2}$ is the hydrocarbon or phenol quantity in the sample after biological degradation, $\mathrm{mg} \mathrm{L}^{-1}$. The phenol degradation rate $\left(Q_{\mathrm{S}}\right.$, $\mathrm{mg} \mathrm{L}^{-1} \mathrm{~h}^{-1}$ ) over the time period of study was calculated according Pirt (1975).

\section{Immobilization of bacterial cells on vermiculite}

Sorptive immobilization of bacterial cells on vermiculite was performed according to Gong et al. (2016) with some modifications. The expanded vermiculite was washed with distilled water three times and dried at $105^{\circ} \mathrm{C}$. The clay was then ground using a laboratory mill (LZM-1, Olis Ltd., Odessa, Ukraine) and screened through a 200 mesh. After autoclaving, $2.5 \mathrm{~g}$ clay powder was added to the flasks containing $100 \mathrm{~mL}$ culture broth (to $0.7 \mathrm{OD}_{540}$ ); flasks were incubated for $3 \mathrm{~h}$ at $220 \mathrm{rpm}$ and $28{ }^{\circ} \mathrm{C}$ to allow sorption of bacterial cells on the vermiculite. The efficiency of bacterial sorption was assessed by the serial dilution technique with plating on agar medium N53. The vermiculite sediment was washed three times with sterile medium N2 and suspended in sterile physiological saline. Samples were used for enumeration of the bacteria firmly attached to vermiculite after preliminary treatment with a UZD-22 ultrasound disrupter (LLC NPP 'Akadempribor', Sumy, Ukraine) set in the following mode: sample processing time twice for $30 \mathrm{~s}$, current strength $0.44 \mathrm{~A}$ and frequency $22 \mathrm{kHz}$.

\section{Scanning electron microscopy of bacterial cells and their interactions with vermiculite}

For scanning electron microscopy, samples of bacterial cells before and after contact with ground vermiculite, where the resulting bacterial-clay sediments were washed twice, were fixed in $2.5 \%$ (vol) glutaraldehyde in $0.1 \mathrm{M}$ phosphate buffer, pH 7.2. Samples were then washed twice with phosphate buffer and dehydrated through a $25-100 \%$ ascending series of ethanol in distilled water, being left for $20 \mathrm{~min}$ at each stage. Two transfers were made in $100 \%$ ethanol, and the samples were dried by the critical point method. Air-dried control samples of ground vermiculite were used. The mounted samples were sputter-coated with $30 \mathrm{~nm} \mathrm{Au} / \mathrm{Pd}$ using Gatan Pecs 682 (Gatan Inc., Pleasanton, CA, USA). Scanning electron microscopy (SEM) was performed using a Tescan Mira 3 LMU scanning electron microscope (Tescan, Brno, Czech Republic).

\section{Statistical analysis}

All experiments were performed in triplicate. The obtained data were analysed with Microsoft Office Excel 2010 software standard package. 


\section{Results}

\section{Phenotypic features}

Strain UCM Ac-602 was found to be an aerobic, Gram-positive, catalase-positive non-motile actinobacterium which does not form spores and has a rod-coccus life cycle. After 20-h cultivation on solid medium 53, cells were rod-shaped (sometimes irregular) or sometimes showed elementary branching; by $48 \mathrm{~h}$, they fragmented into short rods and coccoid forms (Fig. 1a, b).
Cells grown for $24 \mathrm{~h}$ in mineral medium N2 containing $750 \mathrm{mg} \mathrm{L}^{-1}$ phenol are shown in Fig. 1c. The strain formed pink orange colonies of R- and S-types (Fig. 1d). The organism was able to reduce nitrate and degrade starch but not arbutin, casein or xanthine. The basic physiological and biochemical properties of the strain are shown in Table 1. The strain assimilated phenol and showed a high efficiency in degradation of n-hexadecane (99.6\%), kerosene $(94.4 \%)$ as well as diesel fuel (75.5\%). A significantly lower degradation efficiency $(56.2 \%)$ was observed for assimilation of the transformer oil NITRO 11 GX. During
Fig. 1 R. aetherivorans UCM Ac-602 cell morphology. a, b Light microscopy of Gramstained cells grown on agar medium N53 for $\mathbf{a} 20 \mathrm{~h}$ and $\mathbf{b}$ $48 \mathrm{~h}$ (scale bars $=6 \mu \mathrm{m}$ ). $\mathbf{c}$ Scanning electron microscopy image of cells grown for $24 \mathrm{~h}$ in mineral medium N2 with $750 \mathrm{mg} \mathrm{L}^{-1}$ phenol (scale bar = $2 \mu \mathrm{m})$. d S- and R-form colonies of $R$. aetherivorans UCM Ac-602 after 5 days growth on agar medium N53 (scale bar $=3 \mathrm{~mm}$ ). A typical image is shown from several examinations
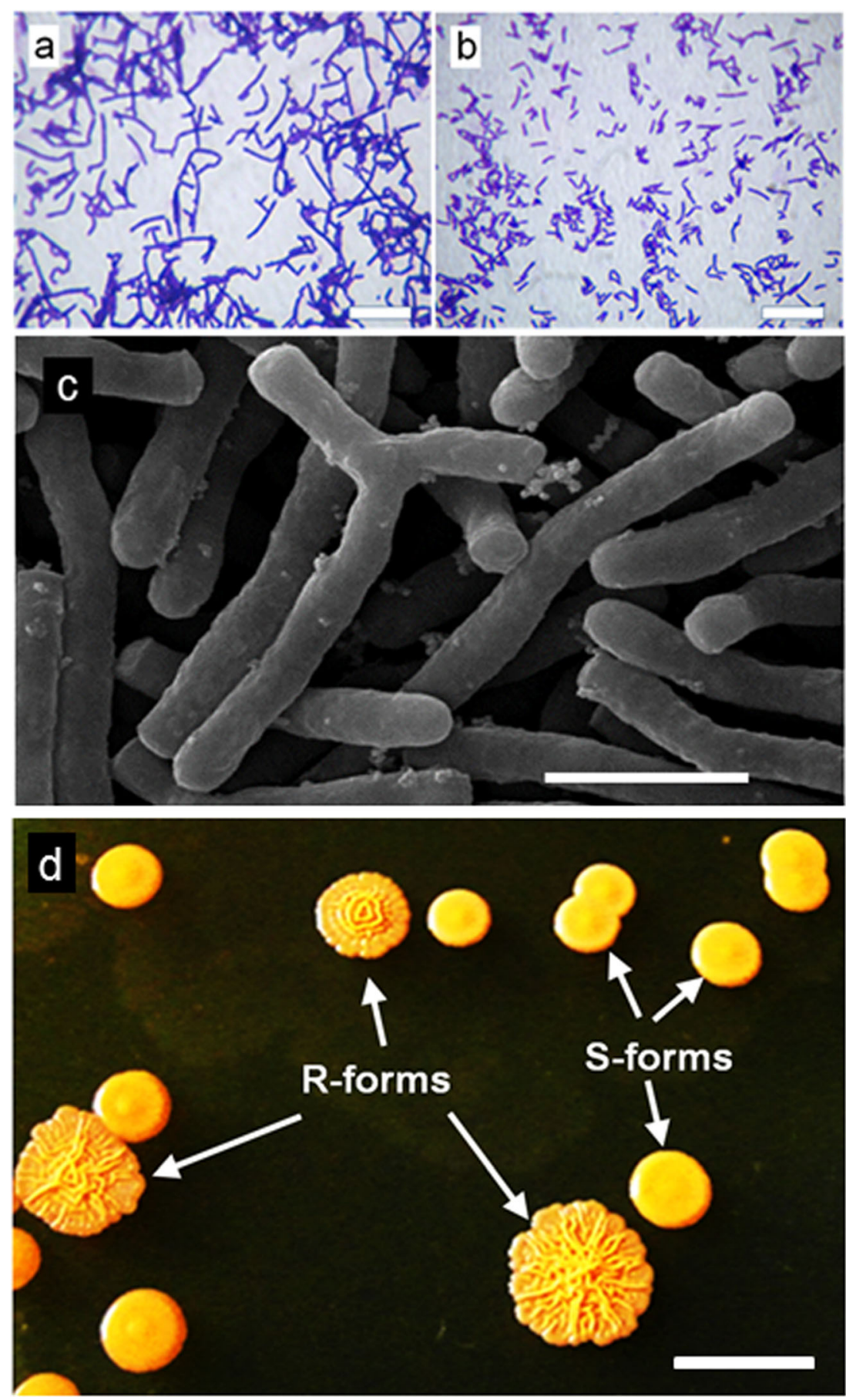
Table 1 Basic physiological and biochemical characteristics of $R$. aetherivorans UCM Ac-602

\begin{tabular}{|c|c|}
\hline Characteristics & UCM Ac-602 \\
\hline Cell size & $0.6-1 \times 4-6 \mu \mathrm{m}$ \\
\hline \multicolumn{2}{|l|}{ Assimilation at $1 \%(w / v)$} \\
\hline $\begin{array}{l}\text { glucose, sucrose, fructose, mannose, melezitose, arabitol, glycerol, } \\
\text { sorbitol, mannitol, xylitol }\end{array}$ & + \\
\hline meso-inositol, $\alpha$-methyl-D-glucoside, arbutine & - \\
\hline \multicolumn{2}{|l|}{ Assimilation at $0.1 \%(w / v)$} \\
\hline $\begin{array}{l}\text { sodium lactate, sodium fumarate, sodium benzoate, sodium butyrate, } \\
\text { sodium citrate, m-hydroxybenzoic acid }\end{array}$ & + \\
\hline sodium gluconate & - \\
\hline \multicolumn{2}{|l|}{ Degradation tests } \\
\hline starch & + \\
\hline arbutin, aesculin, xanthine, gelatine, casein, urea hydrolysis, uric acid & - \\
\hline Ring fission mechanism & ortho-cleavage of phenol \\
\hline
\end{tabular}

determination of the ring fission mechanism by the Rothera's reaction, a cell suspension of the strain failed to show the appearance of a yellow colouration in the presence of catechol, indicating absence of the meta-aromatic ring cleavage. The appearance of a deep purple colour on testing for $b$-keto-adipic acid confirmed the ortho-cleavage of phenol by $R$. aetherivorans UCM Ac-602. The chemotaxonomic study of UCM Ac-602 showed that meso-diaminopimelic acid was the diagnostic cell wall amino acid while arabinose and galactose were the major cell wall sugars indicating that the cell wall is of chemotype IV (Lechevalier and Lechevalier 1970). The strain contained mycolic acids that co-migrated with those of the type strain of R. rhodochrous UCM Ac-744 (= DSMZ 43241). The predominant whole-cell fatty acids (>10\%) in UCM Ac-602 grown on liquid medium 53 included $\mathrm{C}_{16: 0}(33.6 \%), \mathrm{C}_{18: 1}(29.9 \%), \mathrm{C}_{16: 1}$ (10.8\%) and 10-methyl $\mathrm{C}_{18: 0}(9.7 \%)$. According to phenotypic properties, strain UCM Ac-602 belongs to actinobacteria of the genus Rhodococcus (Jones and Goodfellow 2012).

\section{Phylogenetic analysis and identification}

Comparative analysis of the $16 \mathrm{~S}$ rRNA sequence of strain UCM Ac-602 and those of other closely related taxa retrieved from the GenBank database confirmed the strain belonged to the genus Rhodococcus (phylum Actinobacteria). The UCM Ac-602 gene sequence was submitted to the GenBank database with the accession number KP090268. The highest level of sequence similarity (100\%) was revealed between UCM Ac-602 and type strain $R$. aetherivorans DSMZ 44752, followed by $R$. ruber DSM 43338 (99.0\%), R. rhodochrous DSMZ $43241(98.0 \%)$ and $R$. pyridinivorans DSM 44555 $(98.0 \%)$. The high level of similarity between these species was noted earlier by Goodfellow et al. (2004), who showed that these species, together with Rhodococcus coprophilus and Rhodococcus zopfii, formed the $R$. rhodochrous subclade. This was confirmed by our phylogenetic analysis (Fig. 2). $16 \mathrm{~S}$
rRNA sequence similarities between UCM Ac-602 and the type strains of other mycolic-acid-containing taxa varied from 94.0 to $97.0 \%$. The phylogenetic tree determining the position of strain UCM Ac-602 among the species of the Rhodococcus genus showed that this strain formed a common cluster with the type strain of $R$. aetherivorans $10 \mathrm{bc} 312$ tip $=$ DSMZ 44752 (NR 025208) and the other strains of this species: $R$. a et $\bar{h}$ erivorans BCP1 (NZ CM002177) and IcdP1(KR920051) that demonstrated high catabolic potential in relation to a wide range of alkanes as well as of high molecular weight polycyclic aromatic hydrocarbons and chlorinated compounds (Frascari et al. 2006; Cappelletti et al. 2013; Qu et al. 2015). Phylogenetic analysis placed this cluster within the $R$. rhodochrous subclade together with $R$. ruber DSM 43338 (X80625) (Fig. 2). The studied strain also differs from $R$. ruber and other species belonging to the $R$. rhodochrous subclade (Goodfellow et al. 2004) by the complex of diagnostic phenotypic characteristics presented in Table 1. Therefore, based on both genetic and phenotypic studies, it was concluded that strain UCM Ac-602 belongs to the species $R$. aetherivorans.

\section{Phenol biodegradation}

Phenol degradation efficiency by suspended cells of $R$. aetherivorans UCM Ac-602 was determined by monitoring residual phenol content and growth (Fig. 3). It was observed that the time required for complete degradation and growth at all phenol concentrations increased as a function of the initial substrate concentration. At a concentration of $200 \mathrm{mg} \mathrm{L}^{-1}$ (Fig. 3a), residual phenol was absent after $8 \mathrm{~h}$ of growth and the $\mathrm{OD}_{540}$ value increased more than threefold (Fig. 3b). An increase in phenol concentration to 300,500 and $750 \mathrm{mg} \mathrm{L}^{-1}$ resulted in an increase of the time for complete degradation to $10 \mathrm{~h}, 14 \mathrm{~h}$ and $24 \mathrm{~h}$ and $\mathrm{OD}_{540}$ values up to $0.33,0.48$ and 0.65 , respectively (Fig. 3a, b). At an initial phenol concentration $>750 \mathrm{mg} \mathrm{L}^{-1}$, 


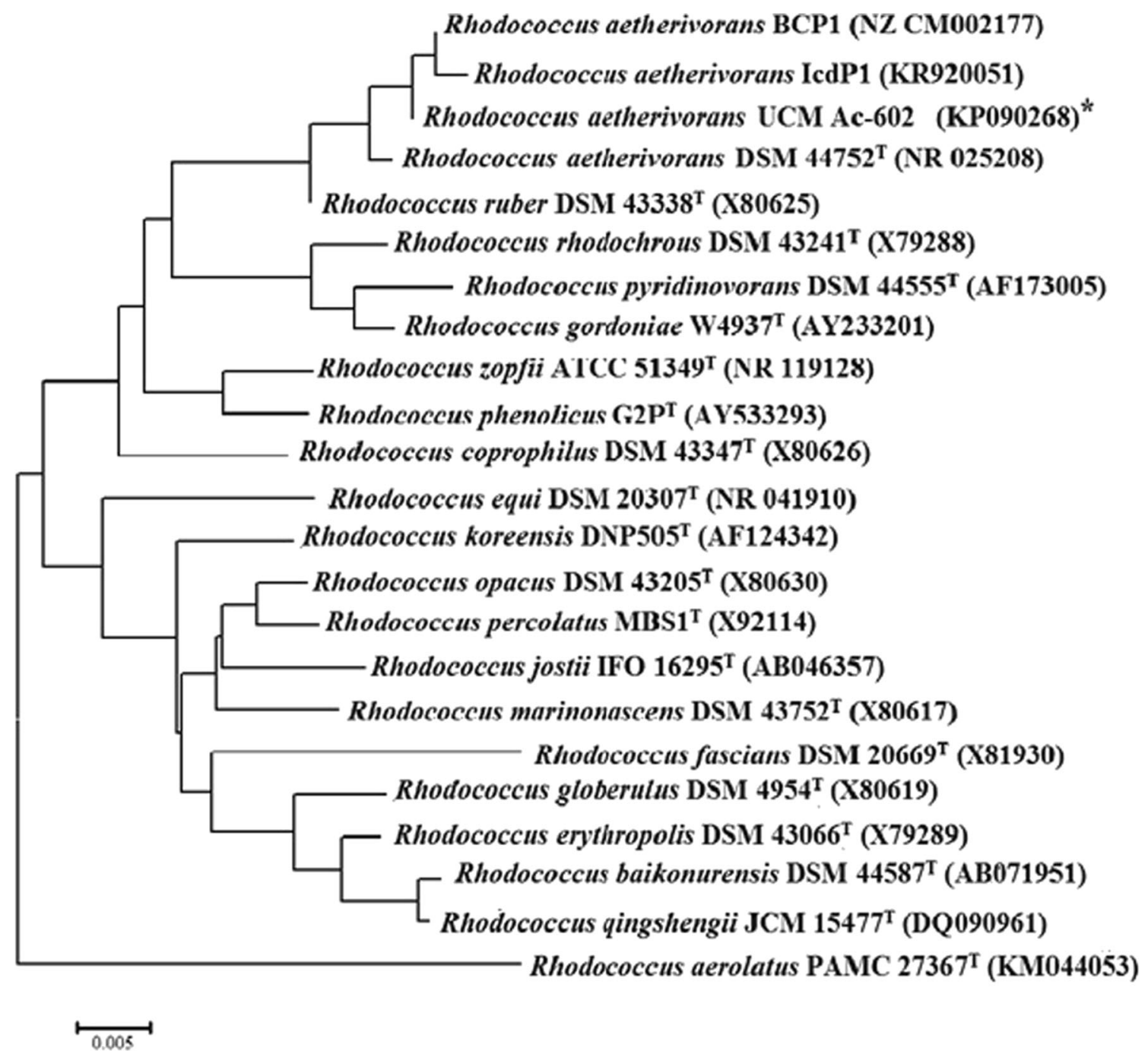

Fig. 2 Neighbour-joining phylogenetic tree based on 16S rRNA gene sequences showing the relationship between strain UCM Ac-602 (*) and type strains of representative Rhodococcus species. The scale bars

complete assimilation occurred after $32 \mathrm{~h}$ at $1000 \mathrm{mg} \mathrm{L}^{-1}$ phenol, $56 \mathrm{~h}$ at $1500 \mathrm{mg} \mathrm{L}^{-1}$ (Fig. 3c) and $96 \mathrm{~h}$ at $1750 \mathrm{mg} \mathrm{L}^{-1}$ (Fig. 3d). It was established that there was a very strong positive correlation with a second-order polynomial regression for phenol concentration vs. biodegradation time (Fig. 4a) and phenol concentration versus biomass yield (Fig. 4b).

The phenol degradation rate $\left(Q_{\mathrm{S}}\right)$ increased with the increase of phenol concentration from 200 to $500 \mathrm{mg} \mathrm{L}^{-1}$, but then decreased (Fig. 5). The highest $Q_{\mathrm{S}}$ (35.7 $\mathrm{mg} \mathrm{L}^{-1} \mathrm{~h}^{-1}$ ) was obtained at an initial phenol concentration of $500 \mathrm{mg} \mathrm{L}^{-1}$. At an initial phenol concentration of 750 and $1000 \mathrm{mg} \mathrm{L}^{-1}$, the $Q_{\mathrm{S}}$ was $31.2 \mathrm{mg} \mathrm{L}^{-1} \mathrm{~h}^{-1}$. The lowest rate values (less than $30 \mathrm{mg} \mathrm{L}^{-1} \mathrm{~h}^{-1}$ ) were observed for the lowest and the highest tested initial phenol concentrations $\left(200,1500\right.$ and $\left.1750 \mathrm{mg} \mathrm{L}^{-1}\right)$. The dependence of $Q_{\mathrm{S}}$ on the phenol concentration was described by a fourth-order polynomial regression $\left(R^{2}=0.9934\right)$. represent 5 substitutions per 1000 nucleotide positions. T is the type strain. GenBank accession numbers are given in parentheses

R. aetherivorans UCM Ac-602 did not grow when the substrate content in the medium reached $2000 \mathrm{mg} \mathrm{L}^{-1}$ (Fig. 6a), but the cells remained viable throughout the entire cultivation period ( $144 \mathrm{~h}$ ) which was confirmed by their ability to subsequently grow on agar medium 53 . To reduce the inhibitory effect of phenol, cells were immobilized on expanded vermiculite which, perhaps like other clay materials, may then have a positive effect on the ability to utilize high phenol concentrations (Shumkova et al. 2009; Gong et al. 2016). Vermiculite-immobilized cells of $R$. aetherivorans UCM Ac602 were able to grow and completely degrade $2000 \mathrm{mg} \mathrm{L}^{-1}$ phenol after $96 \mathrm{~h}$ (Fig. 6a) with the $Q_{\mathrm{S}}=20.8 \mathrm{mg} \mathrm{L}^{-1} \mathrm{~h}^{-1}$ (Fig. 5). In the microorganism-free control, the phenol concentration did not change throughout the experiment proving the absence of interaction between phenol and vermiculite.

In this experiment, the $\mathrm{pH}$ value was reduced to 6.5 after $96 \mathrm{~h}$ growth when the phenol was completely used (Fig. 6b). 
Fig. 3 Growth and phenol degradation by freely-suspended cells of $R$. aetherivorans UCM Ac-602. a phenol degradation and b growth at initial phenol concentrations of (white square) $200 \mathrm{mg} \mathrm{L}^{-1}$, (black triangle) $300 \mathrm{mg} \mathrm{L}^{-1}$, (white circle) $500 \mathrm{mg} \mathrm{L}^{-1}$, (black circle) $750 \mathrm{mg} \mathrm{L}^{-1}$. c Phenol degradation at an initial phenol concentration of (black circle) $1000 \mathrm{mg} \mathrm{L}^{-1}$ and (black square) $1500 \mathrm{mg} \mathrm{L}^{-1}$; growth at an initial phenol concentration of (white circle) $1000 \mathrm{mg} \mathrm{L}^{-1}$ and (white square) $1500 \mathrm{mg} \mathrm{L}^{-1}$. d (Black circle) phenol degradation and (white circle) growth at an initial phenol concentration of $1750 \mathrm{mg} \mathrm{L}^{-1}$. The error bars indicate standard error of the mean $(n=3)$, and when not shown were less than the symbol dimensions
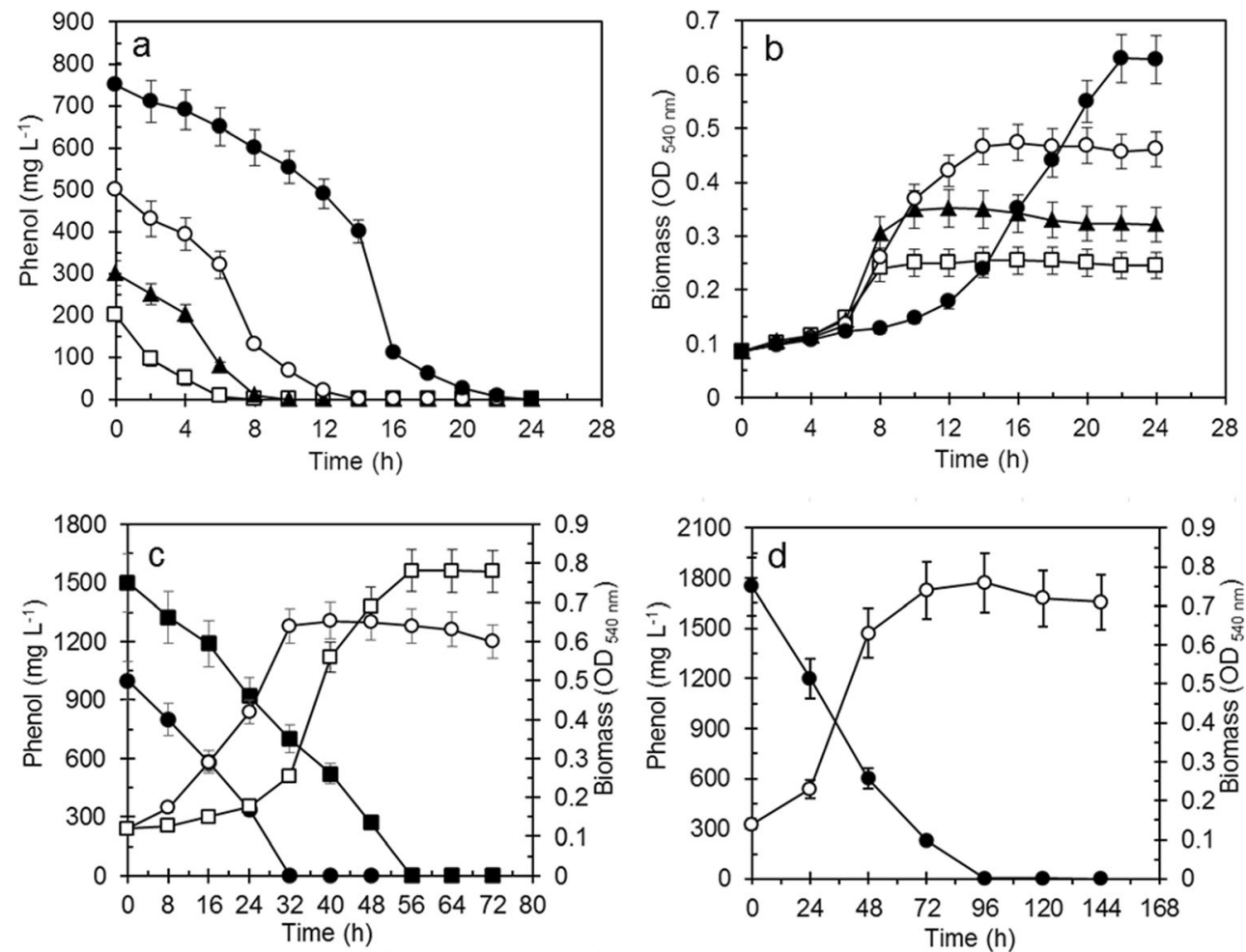

Continued cultivation to $144 \mathrm{~h}$ was accompanied by an increase in $\mathrm{pH}$ to 6.9. In control microorganism-free medium containing only phenol and vermiculite, the $\mathrm{pH}$ remained constant at $\sim 7.2$. In contrast, at the highest initial phenol concentration $1750 \mathrm{mg} \mathrm{L}^{-1}$ utilizable by freely-suspended cells, the $\mathrm{pH}$ values decreased to 5.0 after $96 \mathrm{~h}$ growth when complete degradation of phenol had occurred (Fig. 6b).

The assessment of the interactions between the bacteria and clay mineral showed that the culture broth before cell sorptive immobilization on vermiculite contained $6.1 \times 10^{9} \mathrm{CFU} \mathrm{mL}^{-1}$ and the amount of free planktonic cells in the supernatant after this process was $2.2 \times 10^{9} \mathrm{CFU} \mathrm{mL}^{-1}$, indicating that $63.9 \%$ of bacterial cells were associated with the vermiculite. The number of cells adherent to the clay assessed by triplicate sediment washing and ultrasonic treatment was $1.8 \times$ $10^{8} \mathrm{CFU}$ gram vermiculite ${ }^{-1}$. SEM examination of the bacterial-clay sediments resulting from the sorptive immobilization process demonstrated that cells were not only adsorbed on the surfaces of large vermiculite particles (Fig. 7c, d) but also seemed to be enveloped by small vermiculite particles (Fig. 7e-g). The aggregation of cells and particles was also often observed (e.g. Fig. 7d, e).

Examination of the effect of fractional phenol addition to the culture medium on the degradation ability of suspended cells of $R$. aetherivorans UCM Ac- 602 showed that the introduction of $750 \mathrm{mg} \mathrm{L}^{-1}$ phenol each $24 \mathrm{~h}$ was accompanied by further growth (Table 2). The $\mathrm{OD}_{540}$ after 24-h cultivation was 0.65 , whereas the fractional introduction of additional phenol every $24 \mathrm{~h}$ increased bacterial growth up to $\mathrm{OD}_{540}=2.7$ (=

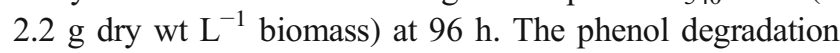
efficiency at each 24-h interval was in the range $99.7-100 \%$ and the cumulative phenol degradation after $96 \mathrm{~h}$ reached
Fig. 4 Correlation between a phenol concentration and degradation time and $\mathbf{b}$ phenol concentration and microbial biomass $\left(\mathrm{OD}_{540}\right)$
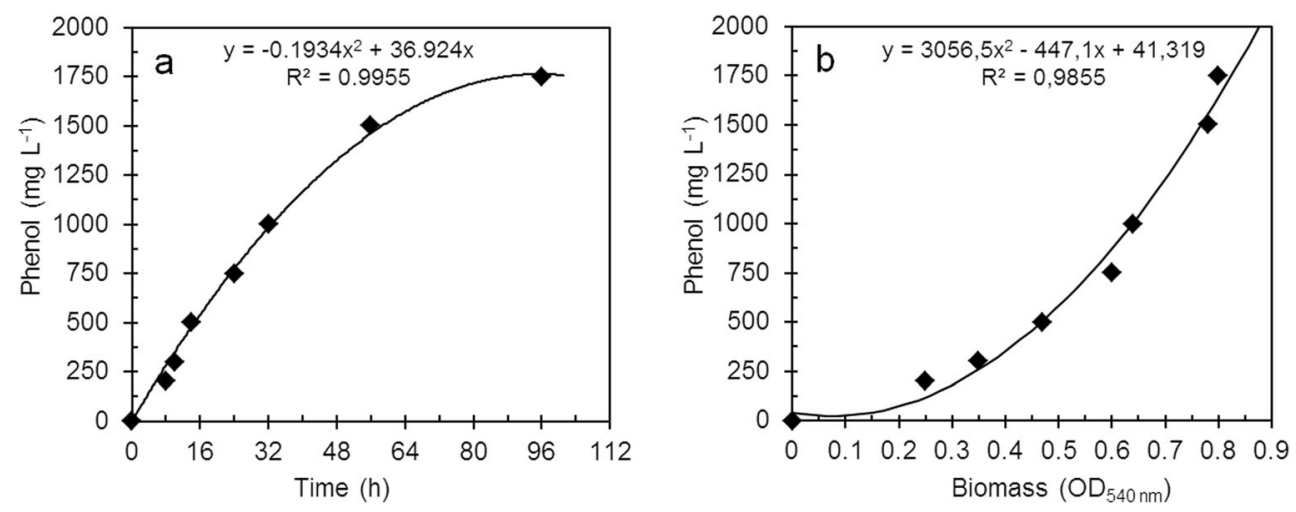


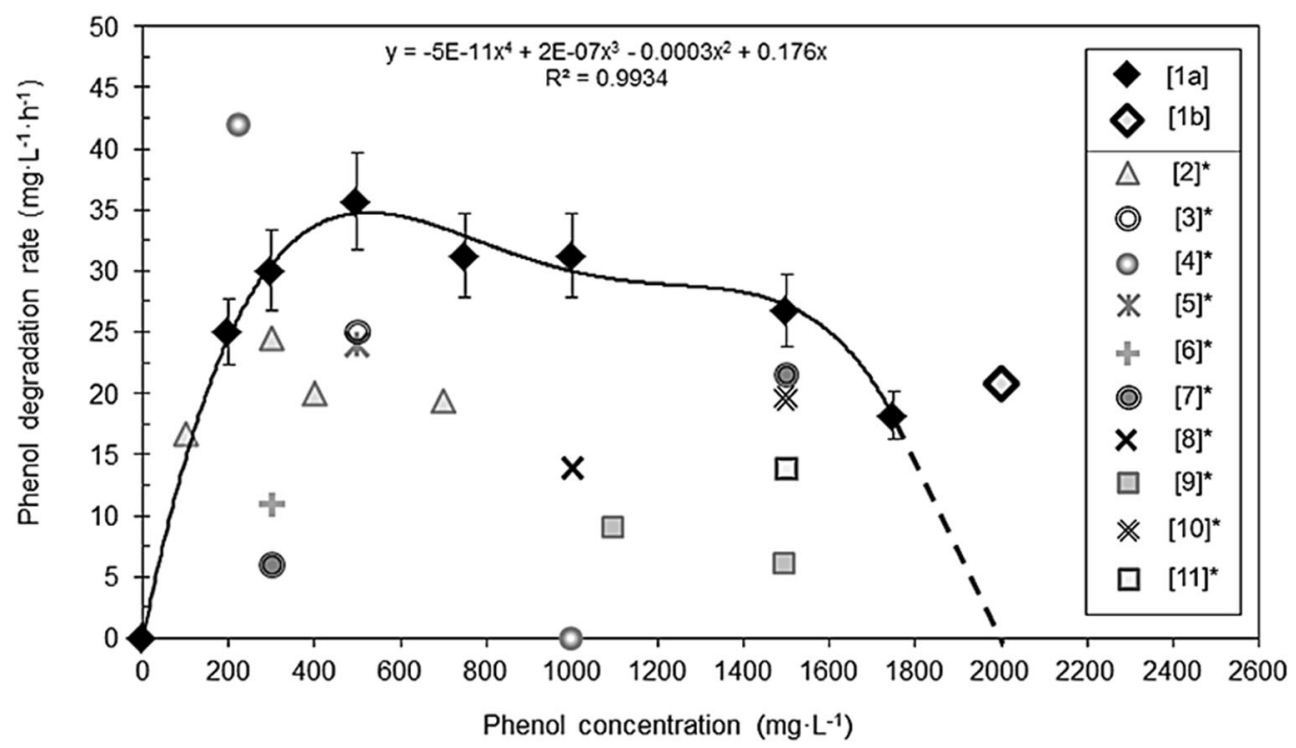

Fig. 5 Phenol biodegradation rates exhibited by $R$. aetherivorans UCM Ac-602 at different phenol concentrations: [1a] freely-suspended cells and [1b] vermiculite-immobilized cells. The error bars indicate standard error of the mean $(n=3)$, and when not shown were less than the symbol dimensions. The data obtained in this study were compared to biodegradation rate values from the literature as follows: [2] mixed microbial culture (Dey and Mukherjee 2010); [3] Pseudomonas sp.

$2998 \mathrm{mg} \mathrm{L}^{-1}$ with specific phenol assimilation being $14.48 \mathrm{nmol} \mathrm{g}$ dry $\mathrm{wt}^{-1}$ ).

\section{Discussion}

Among all the microorganisms listed as efficient phenol assimilators, strains of different Rhodococcus species have been found to be highly resistant to a number of toxic xenobiotics, and their ability to degrade many of these compounds has been reported (Martínková et al. 2009). In this study, the actinobacterial strain $R$. aetherivorans UCM Ac-602 isolated from lubricant-contaminated soil efficiently degraded phenol as well as n-hexadecane, kerosene, diesel fuel and transformer oil. The variable ability to assimilate phenol has been detected for several different species of genus Rhodococcus: $R$. coprophilus (Nagamani and Lowry 2009), R. erythropolis (Soudi and Kolahchi 2011; Korobov et al. 2017; Jha and Veena 2017), R. gordoniae (Mishra and Lal 2014), R. jostii (Zidkova et al. 2010), R. opacus (Shumkova et al. 2009; Yoneda et al. 2016), R. phenolicus (Rehfuss and Urban 2005), R. pyridinivorans (Kumari et al. 2013; Al-Defiery and Gopal 2015; Al-Defiery and Reddy 2013; Moghadam et al. 2016), R. rhodnii (Solyanikova and Golovleva 2015), $R$. rhodochrous (Przybulewska et al. 2006), R. ruber (Pannier et al. 2012) as well as other unidentified strains of Rhodococcus sp. (Suhaila et al. 2010, 2013; Arif et al. 2012; Paisio et al. 2012; Hu et al. 2014; Margesin et al. 2005; Nawawi et al. 2017). Evaluation of phenol degradation in such
SA01 (Mollaei et al. 2010), [4] R. rhodochrous No21 (Przybulewska et al. 2006), [5] Rhodococcus sp. UKMP-5M (Suhaila et al. 2013), [6] Acinetobacter sp. (Khleifat 2007), [7] R. opacus PD630 (Yoneda et al. 2016), [8] P. aeruginosa SPD 10 (Shweta and Dhandayuthapani 2013), [9] Rhodococcus sp. AQ5NOL 2 KCTC 11961BP (Arif et al. 2012), [10] Acinetobacter sp. (Adav et al. 2007), [11] P. pseudomallei NIGB 3 B (Afzal et al. 2007)

studies was carried out under different varying conditions and with initial phenol concentrations ranging from 100 to 200 up to $2000 \mathrm{mg} \mathrm{L}^{-1}$. It is important to note that $1000 \mathrm{mg} \mathrm{L}^{-1}$ frequently appears to be the maximum concentration of phenol used in in vitro experiments. At higher phenol concentrations, the microorganisms could suffer from substrate inhibition where the growth is inhibited and phenol is not degraded (Prieto et al. 2002). There are very few bacteria that can degrade phenol at an initial concentration above $1500 \mathrm{mg} \mathrm{L}^{-1}$ (Nawawi et al. 2014).

Our study, for the first time, has demonstrated the ability of $R$. aetherivorans UCM Ac-602 to biodegrade phenol up to $1750 \mathrm{mg} \mathrm{L}^{-1}$ through an ortho-cleavage pathway, which is a widely distributed mechanism in soil bacteria and fungi (Paisio et al. 2014). This strain is capable of degrading up to $500 \mathrm{mg} \mathrm{L}^{-1}$ phenol without any significant inhibition. However, growth inhibition began to increase when the concentration of phenol was $\geq 750 \mathrm{mg} \mathrm{L}^{-1}$ with complete growth inhibition of freely-suspended cells at $2000 \mathrm{mg} \mathrm{L}^{-1}$.

It should be noted that the often incomplete information on experimental conditions, including media composition, the presence of additional carbon sources, inoculum preparation and adaptation to the toxicant, make a comparative review of available data on phenol degradation by bacteria quite challenging. Therefore, we have analysed only publications that contained clear descriptions of the experimental conditions and quantitative data on phenol degradation (Table 3, Fig. 5).

When considering the known degradation ability of Rhodococcus spp. and other bacteria for phenol 

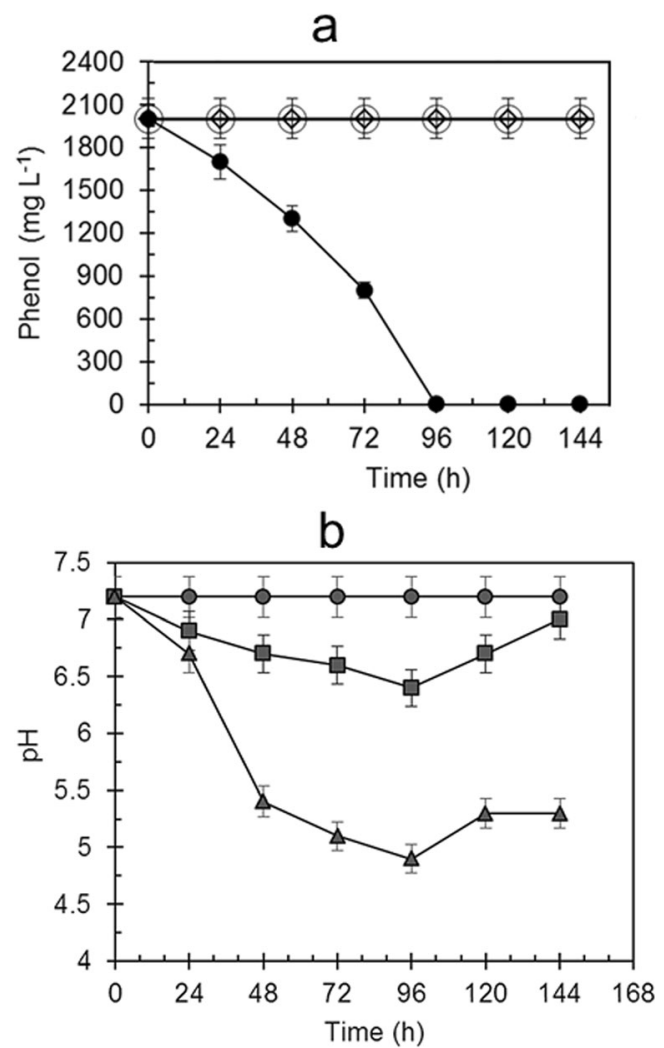

Fig. 6 a Phenol degradation by (white circle) freely-suspended and (black circle) vermiculite-immobilized $R$. aetherivorans UCM Ac-602 cells at an initial phenol concentration of $2000 \mathrm{mg} \mathrm{L}^{-1}$, with (white diamond) abiotic control with phenol and vermiculite without the microorganism; and $\mathbf{b}$ medium $\mathrm{pH}$ changes during growth of $R$. aetherivorans UCM Ac-602 as (black triangle) freely-suspended cells at a phenol concentration of $1750 \mathrm{mg} \mathrm{L}^{-1}$ and (black square) vermiculiteimmobilized cells at a phenol concentration of $2000 \mathrm{mg} \mathrm{L}^{-1}$; (black circle) $\mathrm{pH}$ values for abiotic control medium. The bars indicate standard error of the mean $(n=3)$, and when not shown were less than the symbol dimensions

concentrations above $1000 \mathrm{mg} \mathrm{L}^{-1}$ in terms of (i) the upper limit of the phenol concentrations for assimilation, (ii) the duration of the process, (iii) the extent of phenol degradation and (iv) requirements for additional sources of nutrition and growth stimulants (e.g. yeast extract, urea, thiamine), it is clear that $R$. aetherivorans UCM Ac-602 demonstrated one of the best performances for phenol degradation by both suspended and immobilized cells (Table 3 ).

For freely-suspended cells of Rhodococcus sp. UCC 0009, full degradation of phenol at initial concentrations of 1800 $2100 \mathrm{mg} \mathrm{L}^{-1}$ required more than 12 days (Nawawi et al. 2017), whereas our $R$. aetherivorans UCM Ac-602 achieved full phenol assimilation at an initial concentration of $1750 \mathrm{mg} \mathrm{L}^{-1}$ after only 4 days. The best phenol degrading performance in terms of highest initial phenol concentrations of 2500 and $2600 \mathrm{mg} \mathrm{L}^{-1}$ was recorded for Acinetobacter lowffii UW7 with $61.1 \%$ degradation after 3 days (Liu et al. 2011 ) and Pseudomonas aeruginosa NIBGE MB with $100 \%$ degradation after 7 days (Afzal et al. 2007) (Table 3). The phenol-assimilating activity of freely-suspended cells of our $R$. aetherivorans UCM Ac-602 was limited by an initial phenol concentration of $2000 \mathrm{mg} \mathrm{L}^{-1}$, although the cells remained viable over 6 days cultivation. For vermiculite-immobilized $R$. aetherivorans UCM Ac-602 at an initial phenol concentration of $2000 \mathrm{mg} \mathrm{L}^{-1}$, a similar efficiency of phenol degradation (100\% degradation over $96 \mathrm{~h}$ ) was shown to the best reported example, immobilized biomass of Pseudomonas sp. SA01 (100\% degradation over 100-110 h) (Mollaei et al. 2010). However, in contrast to UCM Ac-602, thiamine addition was required for Pseudomonas sp. SA01 phenol degradation (Table 3). The ability of immobilized Bacillus cereus strains AKG1 MTCC 9817 and AKG2 MTCC 9818 to degrade phenol at an initial concentration of $2000 \mathrm{mg} \mathrm{L}^{-1}$ was significantly lower (53-54\% degradation over 26-36 days) compared to our immobilized strain (Banerjee and Ghoshal 2011).

We regard the phenol degradation rate as the best index of the efficiency of phenol degradation and an essential parameter for biotechnological perspectives. Comparative analysis of phenol degradation rates by suspended bacteria at various initial phenol concentrations was carried for our $R$. aetherivorans UCM Ac-602 and available data for other bacteria (Fig. 5). It was found that $R$. aetherivorans UCM Ac-602 showed excellent phenol degradation ability over a wide range of concentrations with degradation rates significantly exceeding (1.2-5 times) published data for other phenol-assimilating bacteria (Fig. 5). The only exception was a phenol degradation rate of $42 \mathrm{mg} \mathrm{L}^{-1} \mathrm{~h}^{-1}$ reported for $R$. rhodochrous No21, at a low initial phenol concentration $\left(225 \mathrm{mg} \mathrm{L}^{-1}\right)$, which was 1.5 times greater than the degradation rate for our strain at the same initial concentration. However, R. rhodochrous No21 lost the ability to grow as the initial phenol concentration increased to $1000 \mathrm{mg} \mathrm{L}^{-1}$ (Przybulewska et al. 2006).

Cell immobilization and fractional addition of the toxic substrate are often used to achieve a higher efficiency of phenol degradation and to reduce inhibitory effects (Shumkova et al. 2009; Gong et al. 2016; Al-Defiery and Gopal 2015). For example, cells immobilized on vermiculite or polyacrylamide fibres and phenol fractional addition were used by Shumkova et al. (2009) for R. opacus $1 \mathrm{G}$ strain that could not grow as free cells at phenol concentrations exceeding $750 \mathrm{mg} \mathrm{L}^{-1}$ under aerobic batch conditions. The immobilized $R$. opacus $1 \mathrm{G}$ cells showed complete phenol utilization at $1500 \mathrm{mg} \mathrm{L}^{-1}$ over 24 $48 \mathrm{~h}$. Fractional phenol introduction at 250 and $500 \mathrm{mg} \mathrm{L}^{-1}$ resulted in continuation of culture and an increase in the total utilization of substrate. In contrast to $R$. opacus G1, phenol biodegradation by freely-suspended cells of $R$. aetherivorans UCM Ac-602 was significantly higher: this strain can grow and assimilate phenol at initial concentrations up to $1750 \mathrm{mg} \mathrm{L}^{-1}$. At a fractional daily phenol addition of $750 \mathrm{mg} \mathrm{L}^{-1}, 99.9 \%$ of the total added phenol $\left(3000 \mathrm{mg} \mathrm{L}^{-1}\right)$ was degraded after 4 days at a high stable rate during all cycles of operation. Furthermore, our data showed that expanded 


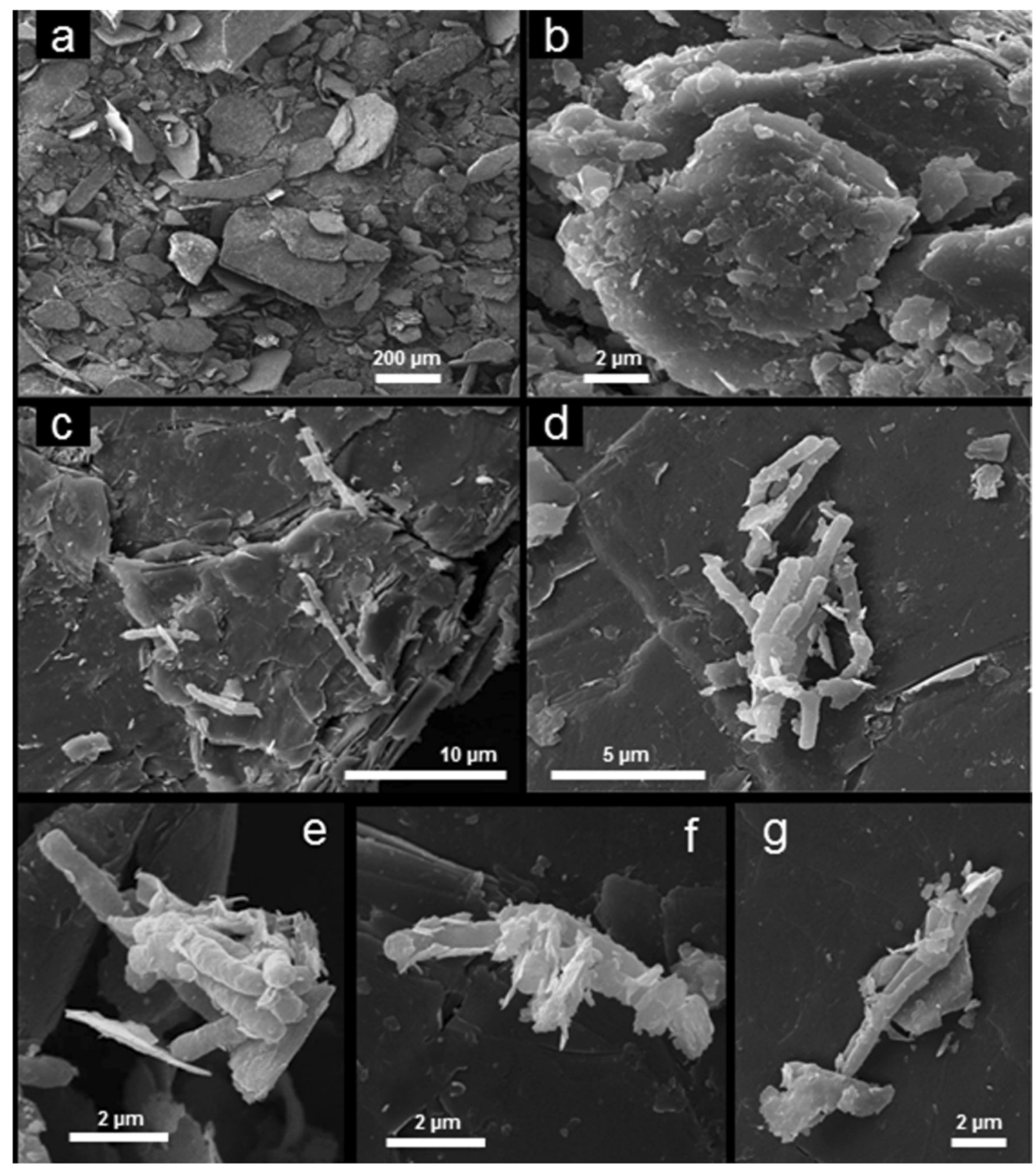

Fig. 7 Scanning electron micrographs of $R$. aetherivorans UCM Ac-602 cell interactions with vermiculite: $\mathbf{a}, \mathbf{b}$ the ground vermiculite used in this study: the size of the crystalline plates varied from 0.2 to $300 \mu \mathrm{m}$; bacterial cells attached to the surface of large vermiculite plates; $\mathbf{d}-\mathbf{g}$ sorption of small $(0.2-2 \mu \mathrm{m})$ vermiculite plates on the surfaces of bacterial cells. Typical images are shown from several examinations
Table 2 The effect of fractional additions of phenol on $R$. aetherivorans UCM Ac-602 degradation ability

\begin{tabular}{llll}
\hline Time $(\mathrm{h})$ & $\mathrm{OD}_{540}$ & $\begin{array}{l}\text { Phenol assimilation for } \\
\text { each } 24 \mathrm{~h}\left(\mathrm{mg} \mathrm{L}^{-1}\right)\end{array}$ & Degradation efficiency ${ }^{\mathrm{a}}(\%)$ \\
\hline 0 & $0.06 \pm 0.002$ & 0 & 0 \\
24 & $0.65 \pm 0.004$ & $750 \pm 27.0$ & 100.0 \\
48 & $1.39 \pm 0.006$ & $749 \pm 26.1$ & $99.9 \pm 1.2$ \\
72 & $1.95 \pm 0.009$ & $749 \pm 26.0$ & $99.7 \pm 2.1$ \\
96 & $2.73 \pm 0.014$ & $750 \pm 27.1$ & $99.7 \pm 2.0$ \\
\hline
\end{tabular}

Bacterial cultivation was performed in medium N2; the initial phenol concentration was $750 \mathrm{mg} \mathrm{L}^{-1}$; the daily fractional introduction of phenol was $750 \mathrm{mg} \mathrm{L}^{-1}$

${ }^{\text {a }}$ Degradation efficiency after each $24 \mathrm{~h}$ of growth. Data are means \pm SD from three independent replicates 


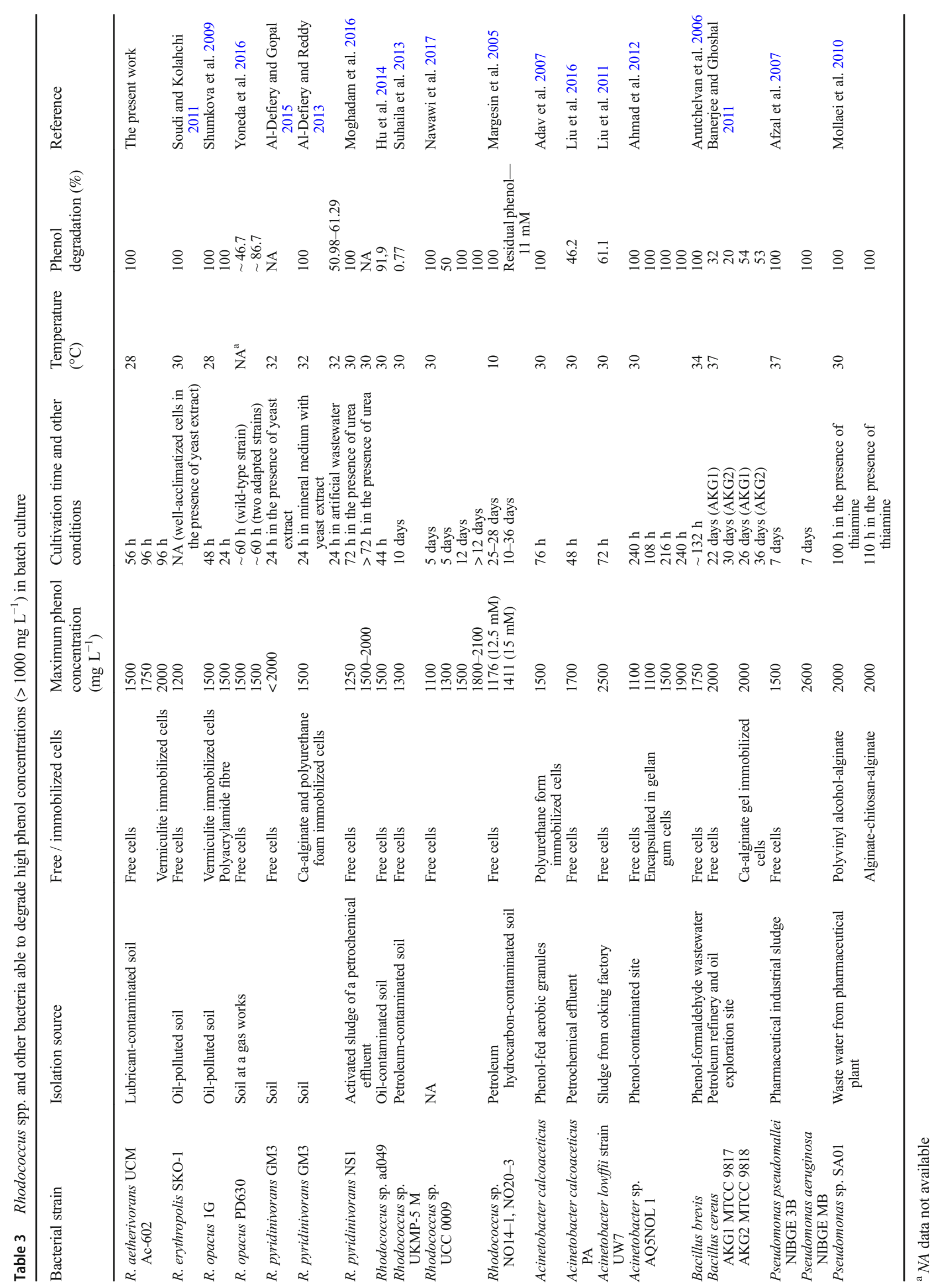


vermiculite was able to improve the phenol degradation efficiency and protect against toxic effects. Numerous studies have shown that interactions of microorganisms with clay adsorbents can lead to an increase in biomass, growth rate and production of enzymes and metabolites (Gadd et al. 2005). Stimulatory effects may arise from the abilities of different clays to serve as (i) $\mathrm{pH}$ buffers, (ii) a source of metal cationic nutrients, (iii) specific adsorbents of metabolic inhibitors, other nutrients and growth stimulators and (iv) modifiers of the microbial microenvironment because of their physicochemical properties such as surface area and adsorptive capacity. As mentioned previously, vermiculite-sorbed $R$. aetherivorans UCM Ac-602 grew and completely degraded $2000 \mathrm{mg} \mathrm{L}^{-1}$ phenol over $96 \mathrm{~h}$. It should be noted that under the conditions of our experiments, the absence of phenol sorption by natural vermiculite was established. This indicated that a decrease of phenol concentration in the culture broth occurred due to biodegradation by the studied strain, and not due to sorption by vermiculite. Our results are in agreement with other data reporting negligible interactions of natural non-modified clays (vermiculite and bentonite) with phenol (the amount of sorbed phenol was $0.05 \mathrm{mmol} \mathrm{g}^{-1}$ of vermiculite) as well as the absence of phenol adsorption on kaolinite (Froehner et al. 2009; Gong et al. 2016). According to Froehner et al. (2009), hydrophobic modification of vermiculite through insertion of hexadecyltrimethylammonium in the mineral interlayer exhibited a high phenol sorption capacity $\left(0.45 \mathrm{mmol} \mathrm{g}^{-1}\right)$. One of the possible reasons for vermiculitesorbed $R$. aetherivorans UCM Ac-602 cells to completely degrade $2000 \mathrm{mg} \mathrm{L}^{-1}$ phenol may be partially due to the buffering effect of vermiculite leading to less significant changes in medium $\mathrm{pH}$ than for freely-suspended cells. The stabilization of $\mathrm{pH}$ in a phenol degradation medium in the presence of another clay mineral, kaolinite, was observed by Gong et al. (2016). The buffering effects of clay minerals are likely to be attributable to adsorption of acidic intermediate products of phenol oxidation. Also observed in this study were the dual interactions between $R$. aetherivorans UCM Ac-602 cells and vermiculite that included both sorption of small particles of vermiculite to the cells and cell attachment to the large mineral plates which resembled observations of the phenol degrading bacterium Sphingomonas sp. GY2B with kaolinite reported by Gong et al. (2016).

In conclusion, the new bacterial isolate from lubricantcontaminated soil, UCM Ac-602, identified as Rhodococcus aetherivorans, demonstrated one of the most efficient phenol degradation rates compared to currently known strains of phenol-degrading bacteria. The phenol-degrading ability of $R$. aetherivorans UCM Ac-602 has been quantitatively characterized as well as its high tolerance to and ability to assimilate phenol and various hydrocarbons. This organism showed phenol degradation over a very wide range of concentrations, up to $2000 \mathrm{mg} \mathrm{L}^{-1}$, and the degradation rate generally considerably exceeded values reported for almost all other bacterial strains. In addition, $R$. aetherivorans UCM Ac-602, unlike many other efficient phenol-degrading bacteria, did not require additional sources of nutrition and growth stimulants for phenol assimilation. $R$. aetherivorans UCM Ac-602 is clearly a promising candidate for bioremediation approaches for phenolcontaminated environments and process streams. The research also contributes further understanding of the Rhodococcus genus as important xenobiotic degrading organisms.

Acknowledgements The authors thank Dr. A.N. Ostapchuk (Zabolotny Institute of Microbiology and Virology of National Academy of Sciences of Ukraine, Kyiv, Ukraine) for the determination of bacterial fatty acids. SM and MF also gratefully acknowledge the United States Department of Defense, Defense Threat Reduction Agency (DTRA) / Ukraine Biological Threat Reduction Program (BTRP) for assistance and support of manuscript development and preparation as a part of the Ukrainian Science Writing Mentorship Program (the contents of this publication are the responsibility of the authors and do not necessarily reflect any views of the DTRA or the United States Government). GMG gratefully acknowledges research support of the Geomicrobiology Group from the Natural Environment Research Council, UK (NE/M011275/1, COG ${ }^{3}$, NE/M010910/1, TeaSe).

Compliance with ethical standards This article does not contain any studies with human participants or animals performed by any of the authors.

Conflict of interest The authors declare that they have no conflict of interest.

Open Access This article is licensed under a Creative Commons Attribution 4.0 International License, which permits use, sharing, adaptation, distribution and reproduction in any medium or format, as long as you give appropriate credit to the original author(s) and the source, provide a link to the Creative Commons licence, and indicate if changes were made. The images or other third party material in this article are included in the article's Creative Commons licence, unless indicated otherwise in a credit line to the material. If material is not included in the article's Creative Commons licence and your intended use is not permitted by statutory regulation or exceeds the permitted use, you will need to obtain permission directly from the copyright holder. To view a copy of this licence, visit http://creativecommons.org/licenses/by/4.0/.

\section{References}

Adav SS, Chen MY, Lee DJ, Ren NQ (2007) Degradation of phenol by Acinetobacter strain isolated from aerobic granules. Chemosphere 67:1566-1572. https://doi.org/10.1016/j.chemosphere.2006.11.067

Afzal M, Iqbal S, Rauf S, Khalid ZM (2007) Characterization of phenol biodegradation in saline solutions by monocultures of Pseudomonas aeruginosa and Pseudomonas pseudomallei. J Hazard Mater 149:60-66

Ahmad SA, Shamaan NA, Arif NM, Koon GB, Shukor MYA, Syed MA (2012) Enhanced phenol degradation by immobilized Acinetobacter sp. strain AQ5NOL 1. World J. Microb Biotechnol 28:347-352. https://doi.org/10.1007/s11274-011-0826-Z 
Al-Defiery ME, Gopal R (2015) Viability, survivability and tolerability of Rhodococcus pyridinivorans GM3 for phenol concentrations. Mesopotamia Environ J 1:57-65

Al-Defiery MEJ, Reddy G (2013) Application of immobilized cells of Rhodococcus pyridinivorans GM3 for phenol degradation in batch culture. Proceeding of the Second International Conference on Agriculture and Natural Resources. Razi University, KermanshahIran. December 25-26. P. 857-861

APHA (2005) Standard methods for the examination of water and wastewater, 21st edn. American Public Health Association, Washington, DC

Arif NM, Ahmad SA, Syed MA, Shukor MY (2012) Isolation and characterization of a phenol-degrading Rhodococcus sp. strain AQ5NOL 2 KCTC 11961BP. J Basic Microbiol 53:9-19. https:// doi.org/10.1002/jobm.201100120

Arutchelvan V, Kanakasabai V, Elangovan R, Nagarajan S, Muralikkrishnan V (2006) Kinetics of high strength phenol degradation using Bacillus brevis. J Hazard Mater 129:216-222

Banerjee A, Ghoshal AK (2011) Phenol degradation performance by isolated Bacillus cereus immobilized in alginate. Int Biodeterior Biodegradation 65:1052-1060. https://doi.org/10.1016/j.ibiod. 2011.04.011

Cappelletti M, Di Gennaro P, D’Ursi P, Orro A, Mezzelani A, Landini M, Fedi S, Frascari D, Presentato A, Zannoni D, Milanesi L (2013) Genome sequence of Rhodococcus sp. strain BCP1, a biodegrader of alkanes and chlorinated compounds. Genome Announc 1(5): e00657-e00613. https://doi.org/10.1128/genomeA.00657-13

Dey S, Mukherjee S (2010) Performance and kinetic evaluation of phenol biodegradation by mixed microbial culture in a batch reactor. Int $\mathrm{J}$ Water Res Environ Eng 2:40-49

Shweta, Dhandayuthapani K (2013) Influence of media supplements on phenol biodegradation by Pseudomonas aeruginosa SPD10. Int J Curr Microbiol App Sci 2:64-69

Frascari D, Pinelli D, Nocentini M, Fedi S, Pii Y, Zannoni D (2006) Chloroform degradation by butane-grown cells of Rhodococcus aetherovorans BCP1. Appl Microbiol Biotechnol 73:421-428. https://doi.org/10.1007/s00253-006-0433-3

Froehner S, Martins RF, Furukawa W, Errera MR (2009) Water remediation by adsorption of phenol onto hydrophobic modified clay. Water Air Soil Pollut 199:107-113

Gadd GM, Fomina M, Burford EP (2005) Fungal roles and functions in rock, mineral and soil transformations. In Microorganisms and Earth Systems-Advances in Geomicrobiology. Ed. by GM Gadd, KT Semple, HM Lappin-Scott. Cambridge University Press, Cambridge. pp. 201-232

Gami AA, Shukor MY, Khalil KA, Dahalan FA, Khalid A, Ahmad SA (2014) Phenol and phenolic compounds toxicity. J Environ Microbiol Toxicol 2:11-24

Gong B, Wu P, Huang Z, Lia Y, Zhi D, Ruan B, Kang C, Zhu N (2016) Enhanced degradation of phenol by Sphingomonas sp. GY2B with resistance towards suboptimal environment through adsorption on kaolinite. Chemosphere 148:388-394

Goodfellow M, Thomas EG, Ward AC, James AL (1990) Classification and identification of rhodococci. Zbl Bakt 274:299-315

Goodfellow M, Jones AL, Maldonado LA, Salanitro J (2004) Rhodococcus aetherivorans sp. nov., a new species that contains methyl t-butyl ether-degrading actinomycetes. Syst Appl Microbiol 27:61-65

Hu T, Gu J, Zhen L, Yang J, Shi L, Wang X, Gao H (2014) Identification and characteristics of phenol degrading bacteria ad049 screened from oil contaminated soil. Acta Ecol Sin 34:1140-1148 (in Chinese). https://doi.org/10.5846/stxb201306091528

Jha JK, Veena BR (2017) Effect of temperature and cell carrier loading on phenol degradation using Rhodococcus erythropolis. Int J Eng Sci Comp 7:15479-15482
Jones AL, Goodfellow M (2012) Genus IV. Rhodococcus (Zopf 1891) emend. Goodfellow, Alderson and Chun 1998a. In: Goodfellow M, Kämpfer P, Busse H-J, Trujillo ME, Suzuki K, Ludwig W, Whitman WB (eds) Bergey's Manual of Systematic Bacteriology, 2nd end, vol. 5. The Actinobacteria, part a. springer, new-York, pp 437-464

Khleifat KM (2007) Biodegradation of phenol by Actinobacillus sp.: mathematical interpretation and effect of some growth conditions. Bioremed J 11:103-112. https://doi.org/10.1080/ 10889860701429328

Kim BH, Gadd GM (2019) Prokaryotic Metabolism and Physiology. Cambridge University Press, Cambridge

Kimura M (1980) A simple method for estimating evolutionary rate of base substitutions through comparative studies of nucleotide sequences. J Mol Evol 16:111-120

Korobov VV, Zhurenko EI, Zharikova NV, Iasakov TR, Markusheva TV (2017) Possibility of using phenol- and 2,4-dichlorophenoldegrading strain, Rhodococcus erythropolis $17 \mathrm{~S}$, for treatment of industrial wastewater. Mosc Univ Biol Sci Bull 72:201-205. https://doi.org/10.3103/s0096392517040083

Kumari S, Chetty D, Ramdhani N, Bux F (2013) Phenol degrading ability of Rhodococcus pyrinidivorans and Pseudomonas aeruginosa isolated from activated sludge plants in South Africa. J Environ Sci Health, Part A: Tox Hazard Subst Environ Eng 48:947-953. https:// doi.org/10.1080/10934529.2013.762740

Kuyukina MS, Ivshina IB (2010) Application of Rhodococcus in bioremediation of contaminated environments. In: Steinbuchel A (ed) Microbiology Monographs. Springer-Verlag, Dordrecht, pp 231-262

Lane DG (1991) 16S/23S rRNA sequencing. In: Stackebrandt E, Goodfellow M (eds) Nucleic acids techniques in bacterial systematic. Wiley, New York, pp 115-175

Lechevalier MP, Lechevalier HA (1970) Chemical composition as a criterion in the classification of aerobic actinomycetes. Int J Syst Bacteriol 20:435-443. https://doi.org/10.1099/00207713-20-4-435

Lin SH, Chuang TS (1994) Combined treatment of phenolic wastewater by wet air oxidation and activated sludge. Toxicol Environ Chem 44:243-258

Liu G, Hao X, Duan P, Hou Y, Qin W (2011) Identification and characteristics of a phenol-degrading bacterium UW7. China J Appl Environ Biol 17:118-120

Liu Z, Xie W, Li D, Peng Y, Li Z, Liu S (2016) Biodegradation of phenol by bacteria strain Acinetobacter calcoaceticus $\mathrm{PA}$ isolated from phenolic wastewater. Int J Environ Res Public Health 13:300. https:// doi.org/10.3390/ijerph13030300

Margesin R, Fonteyne PA, Redl B (2005) Low-temperature biodegradation of high amounts of phenol by Rhodococcus spp. and basidiomycetous yeasts. Res Microbiol 156:68-75. https://doi.org/10.1016/ j.resmic.2004.08.002

Marrot B, Barrios-Martinez A, Moulin P, Roche N (2006) Biodegradation of high phenol concentration by activated sludge in an immersed membrane bioreactor. Biochem Eng J 30:174-183

Martínková L, Uhnáková B, Pátek M, Nešvera J, Křen V (2009) Biodegradation potential of the genus Rhodococcus. Environ Int 35:162-177

Michalowicz J, Duda W (2007) Phenols - sources and toxicity. Pol J Environ Stud 16:347-362

Minnikin DE, Hutchinson IG, Caldicott AB, Goodfellow M (1980) Thinlayer chromatography of methanolysates of mycolic acid-containing bacteria. J Chromatogr 188:221-233

Mishra V, Lal R (2014) Enhanced degradation of phenol by a new species of Rhodococcus: $R$. gordoniae through ortho-pathway. Int J Basic Appl Biol 1:23-26

Moghadam MS, Safaei N, Ebrahimipour GH (2016) Optimization of phenol biodegradation by efficient bacteria isolated from petrochemical effluents. Global J Environ Sci Manag 2:249-256. https://doi.org/10.7508/gjesm.2016.03.004 
Mollaei M, Abdollahpour S, Atashgahi S, Abbasi H, Masoomi F, Rad I, Lotfi AS, Zahiri HS, Vali H, Noghabi KA (2010) Enhanced phenol degradation by Pseudomonas sp. SA01: gaining insight into the novel single and hybrid immobilizations. J Hazard Mater 175: 284-292. https://doi.org/10.1016/j.jhazmat.2009.10.002

Nagamani A, Lowry M (2009) Phenol biodegradation by Rhodococcus coprophilus isolated from semi arid soil samples of Pali, Rajasthan. Int J Appl Environ Sci 4:295-302

Nawawi NM, Ahmad SA, Shukor MY, Syed MA, Ibrahim AL (2014) Isolation and characterization of phenol-degrading microorganism: recent advances. J Environ Biorem Toxicol 2:11-22

Nawawi NM, Ahmad SA, Ibrahim AL (2017) Effect of different phenol concentration on phenol degradation by Rhodococcus spp. Indian J Fund Appl Life Sci 7:39-44

Ottow JCG, Zolg W (1974) Improved procedure and colorimetric test for the detection of ortho- and meta-cleavage of protocatechuate by Pseudomonas isolates. Can J Microbiol 20:1059-1061

Paisio CE, Talano MA, González PS, Busto VD, Talou JR, Agostini E (2012) Isolation and characterization of Rhodococcus strain with phenol-degrading ability and its potential use for tannery effluent biotreatment. Environ Sci Pollut Res 19:3430-3439. https://doi. org/10.1007/s11356-012-0870-8

Paisio CE, Oller ALW, Ibañez SG, Talano MA, González PS, Medina MI, Agostini E (2014). Bioremediation as a useful biotechnological strategy for the treatment of phenolics: advances, challenges and future prospects. Chapter 4. In Bioremediation: Processes, Challenges and Future Prospects. Ed. by J.B. VelázguesFernández, S. Muñiz-Hernándes. Nova Science Publishers, New York. pp. 57-79

Pannier A, Mkandawire M, Soltmann U, Pompe W, Böttcher H (2012) Biological activity and mechanical stability of sol-gel-based biofilters using the freeze-gelation technique for immobilization of Rhodococcus rubber. Appl Microbiol Biotechnol 93:1755-1767. https://doi.org/10.1007/s00253-011-3489-7

Park JY, Hong JW, Gadd GM (2009) Phenol degradation by Fusarium oxysporum GJ4 is affected by toxic catalytic polymerization mediated by copper oxide. Chemosphere 75:765-771

Pirt SJ (1975) Principles of Cell Cultivation. Blackwell Scientific, London

Prieto MB, Hidalgo A, Serra JL, Llama MJ (2002) Degradation of phenol by Rhodococcus erythropolis UPV-1 immobilized on Biolite ${ }^{\circledR}$ in a packed-bed reactor. J Biotechnol 97:1-11

Przybulewska K, Wieczorek A, Nowak A, Pochrzaszcz M (2006) The isolation of microorganisms capable of phenol degradation. Pol J Microbiol 55:63-67

Qu J, Miao L-L, Liu Y, Liu Z-P (2015) Complete genome sequence of Rhodococcus sp. strain IcdP1 shows diverse catabolic potential. Genome Announc 3(4):e00711-e00715. https://doi.org/10.1128/ genomeA.00711-15

Rehfuss M, Urban J (2005) Rhodococcus phenolicus sp. nov., a novel bioprocessor isolated actinomycete with the ability to degrade chlorobenzene, dichlorobenzene and phenol as sole carbon sources. Syst Appl Microbiol 28:695-701. https://doi.org/10.1016/j.syapm.2005.05.011

Saitou N, Nei M (1987) The neighbor-joining method: a new method for reconstructing phylogenetic trees. Mol Biol Evol 4:406-425

Shaban YA, El-Sayed MA, El-Maradny AA, Al-Farawati RK, Al-Zobidi MI (2013) Photocatalytic degradation of phenol in natural seawater using visible light active carbon modified $(\mathrm{CM})-\mathrm{n}-\mathrm{TiO}_{2}$ nanoparticles under UV light and natural sunlight illuminations.
Chemosphere 91:307-313. https://doi.org/10.1016/j.chemosphere. 2012.11.035

Shumkova ES, Solyanikova IP, Plotnikova EG, Golovleva LA (2009) Phenol degradation by Rhodococcus opacus strain 1G. Appl Biochem Microbiol 45:43-49. https://doi.org/10.1134/ S0003683809010086

Smibert RM, Krieg NR (1994) Phenotypic characterization. In: Gerhardt P, Murray RGE, Wood WA, Krieg NR (eds) Methods for General and Molecular Bacteriology. American Society for Microbiology, Washington, DC, pp 607-654

Smirnova VS, Khudorozhkova SA, Ruchkinova OI (2017) Dephenolization of highly concentrated wastewater from industrial enterprises. Bull perm National res Polytechnic Univ. construction and architecture. 8: 52-63. Doi: https://doi.org/10.15593/22249826/2017.2.05

Solyanikova IP, Golovleva LA (2015) Physiological and biochemical properties of actinobacteria as the basis of their high biodegradative activity (review). Appl Biochem Microbiol 51:143-149. https://doi. org/10.1134/S0003683815020180

Solyanikova IP, Konovalova EI, Shumkova ES, Plotnikova EG, Golovleva LA (2010) Bacteria of the genus Rhodococcuspromising destructors of stable pollutants for sewage treatment. Water: Chem Ecol 4:18-26 (in Russian). http://watchemec.ru/ article/10690/

Soudi MR, Kolahchi N (2011) Bioremediation potential of a phenol degrading bacterium, Rhodococcus erythropolis SKO-1. J Prog Biol Sci 1:31-40

Staneck JL, Roberts GD (1974) Simplified approach to identification of aerobic actinomycetes by thin layer chromatography. Appl Microbiol 28:226-231

Suhaila YN, Ariff AB, Rosfarizan M, Latif IA, Ahmad SA, Norazah MN, Shukor MYA (2010) Optimization of parameters for phenol degradation by Rhodococcus UKM-P in shake flask culture. Proc World Congress Engineering, June 30 - July 2, 2010, London, U.K., pp. 601-604

Suhaila YN, Rosfarizan M, Ahmad SA, Latif IA, Ariff AB (2013) Nutrients and culture conditions requirements for the degradation of phenol by Rhodococcus UKMP-5M. J Environ Biol 34:635-643

Tamura K, Peterson D, Peterson N, Stecher G, Nei M, Kumar S (2011) MEGA5: molecular evolutionary genetics analysis using maximum likelihood, evolutionary distance, and maximum parsimony methods. Mol Biol Evol 28:2731-2739. https://doi.org/10.1093/ molbev/msr121

Yoneda A, Henson WR, Goldner NK, Park KJ, Forsberg KJ, Kim Soo J, Pesesky MW, Foston M, Dantas G, Moon TS (2016) Comparative transcriptomics elucidates adaptive phenol tolerance and utilization in lipid-accumulating Rhodococcus opacus PD630. Nucleic Acids Res 44:2240-2254 https://digitalcommons.wustl.edu/open_access_ pubs $/ 4897$

Zidkova L, Otevrel M, Wimmerova L, Patek M (2010) Continuous phenol degradation in wastewater by Rhodococcus jostii RHA1; model batch test and continuous verification in a biofilter J Biotech Special Abstracts 150: 215 [P-E.14]. doi:https://doi.org/10.1016/j.jbiotec. 2010.09 .036

Publisher's note Springer Nature remains neutral with regard to jurisdictional claims in published maps and institutional affiliations. 